\title{
Synthesis and bio-catalytic activity of isostructural cobalt(III)-phenanthroline complexes
}

\author{
DHANANJAY DEY ${ }^{\mathrm{a}}$, ARNAB BASU ROY ${ }^{\mathrm{a}}$, ANANDAN RANJANI ${ }^{\mathrm{b}}$, \\ LOGANATHAN GAYATHRI ${ }^{\mathrm{b}}$, SARAVANAN CHANDRALEKA ${ }^{\mathrm{b}, \S}$, \\ DHARUMADURAI DHANASEKARAN ${ }^{\mathrm{b}}$, MOHAMMAD ABDULKADER AKBARSHA ${ }^{\mathrm{c}}$, \\ CHUNG-YU SHEN ${ }^{\mathrm{d}}$, HUI-LIEN TSAI ${ }^{\mathrm{d}}$, MILAN MAJI ${ }^{\mathrm{e}}$, NIRANJAN KOLE ${ }^{\mathrm{a}}$ and \\ BHASKAR BISWAS ${ }^{\mathrm{a}, *}$ \\ ${ }^{a}$ Department of Chemistry, Raghunathpur College, Purulia 723133, India \\ ${ }^{b}$ Department of Microbiology, Bharathidasan University, Tiruchirappalli 620 024, India \\ ${ }^{\mathrm{c}}$ Mahatma Gandhi-Doerenkamp Centre, Bharathidasan University, Tiruchirappalli 620 024, India \\ ${ }^{\mathrm{d}}$ Department of Chemistry, National Cheng Kung University, Tainan City, 70101, Taiwan \\ ${ }^{e}$ Department of Chemistry, National Institute of Technology, Mahatma Gandhi Avenue, \\ Durgapur 713209, India \\ $\S$ Present address: Department of Chemistry, Urumu Dhanalakshmi College, Tiruchirappalli 620019, India \\ e-mail: mr.bbiswas@ rediffmail.com; icbbiswas@gmail.com
}

MS received 02 July 2014; revised 06 November 2014; accepted 10 November 2014

\begin{abstract}
We have synthesized two isostructural mononuclear cobalt(III) complexes $[\mathbf{1}] \mathrm{NO}_{3} \cdot 3 \mathrm{H}_{2} \mathrm{O}$ and $[1] \mathrm{NO}_{3} \cdot \mathrm{CH}_{3} \mathrm{CO}_{2} \mathrm{H} \cdot \mathrm{H}_{2} \mathrm{O}\left\{[1]^{+}=\left[\mathrm{Co}(1,10 \text {-phenanthroline })_{2} \mathrm{Cl}_{2}\right]^{+}\right\}$and characterized by single crystal X-ray structural analyses. Mass spectral studies of the complexes indicate both the compounds to produce identical cationic species viz., $\left[\mathrm{Co}(\text { phen })_{2} \mathrm{Cl}_{2}\right]^{+}$in methanol solution. $[1]^{+}$has been evaluated as model system for the catechol oxidase enzyme by using 3,5-di-tert-butylcatechol (3,5-DTBC) as the substrate in methanol medium, which revealed that the cationic complex efficiently inhibits catalytic activity with $\mathrm{k}_{\text {cat }}$ value $9.65 \times 10^{2} \mathrm{~h}^{-1}$. $[1]^{+}$cleaved pBR 322 DNA without addition of an activating agent. Further, the anti-cancer activity of $[\mathbf{1}]^{+}$on human hepatocarcinoma cell line (HepG2) has been examined. The induction of apoptosis induced in the cell line was assessed base on the changes in cell morphology, which showed the efficacy of [1] ${ }^{+}$to induce apoptosis in $53 \%$ of cells during $24 \mathrm{~h}$ treatment. Interestingly, the observed $\mathrm{IC}_{50}$ values reveal that $[\mathbf{1}]^{+}$brings about conformational change on DNA strongly and exhibits remarkable cytotoxicity.
\end{abstract}

Keywords. Cobalt(III); X-ray structure; Catecholase activity; DNA cleavage; Anti-cancer activity.

\section{Introduction}

Cobalt(III) compounds of polycyclic heteroaromatics with transition metals form a class of DNA interacting substances that have received considerable attention over the years, as they combine properties of traditional DNA interacting polycyclic aromatics with important photophysical and photochemical potentials offered by the metal into rigid structures spanning all three dimensions. ${ }^{1-3}$ The design of small cationic molecules that react at specific sequences of DNA under physiological conditions via oxidative and hydrolytic cleavage has been attracting great interest in the field of bioinorganic chemistry. The application of octahedral complexes has allowed the targeting of specific DNA sites by matching the shape, symmetry and functionality of the

*For correspondence metal complex to those of the DNA target. ${ }^{4}$ Due to the unusual binding properties and general photo-activity, these coordination compounds are candidates available as DNA secondary structure probes, photocleavers and anti-tumour drugs. ${ }^{5-8}$

The oxidation of organic compounds is an important and widely used reaction in laboratory scale organic synthesis as well as in large scale chemical industry. ${ }^{9-11}$ An ideal oxidant for any large scale oxidation reaction should be easily accessible, cheap and non-toxic like dioxygen. ${ }^{12-14}$ It is easily available since it is present in air and the only by-product produced from its decomposition is water. In this respect, the oxidation of a wide range of $o$-diphenols (catechols), such as caffeic acid, to the corresponding quinones using molecular oxygen as oxidant and a copper enzyme Catechol Oxidase $\left(\mathrm{CO}_{\mathrm{x}}\right)$, as catalyst has received considerable attraction to reveal mechanistic aspect, catalytic activity, product formation 
selectivity, structure-reactivity relationship and so on. ${ }^{15-17}$ The quinines which are highly reactive compounds undergo auto-polymerization leading to the formation of a brown polyphenolic pigment, i.e. melanin, a process thought to protect a damaged tissue against pathogens or insects. ${ }^{18}$ Though cobalt complexes have been regarded as very efficient and selective catalysts towards different organic transformations, cobalt(III)phenanthroline complexes as biomimetic models of catechol oxidase have not been extensively studied. ${ }^{19-21}$

Herein, we report two new isostructural mononuclear cobalt(III)-phenanthroline complexes containing hetero anions and solvate molecules in Co(III)-1,10phenanthroline crystalline host at room temperature. We have investigated the catalytic activity of $[\mathbf{1}]^{+}$, $\left\{[\mathbf{1}]^{+}=\left[\mathrm{Co}(1,10 \text {-phenanthroline })_{2} \mathrm{Cl}_{2}\right]^{+}\right\}$, towards 3,5$d i$-tert-butylcatechol as bio-mimetic model for catecholase oxidase in methanolic medium. Since detailed investigation of DNA binding and DNA photocleavage studies for cis-dichlorobis(diimine)cobalt(III)chloride complexes was performed by Joshi et al in 2006, ${ }^{22}$ we have explored the cleavage efficiency on pBR 322 DNA without adding any external agents. Also, $[1]^{+}$ proved to be an efficient cytotoxic agent against human hepatocellular carcinoma cell line HepG2.

\section{Experimental}

\subsection{Preparation of the complexes}

2.1a Chemicals, solvents and starting materials: High purity 1,10-phenanthroline (Lancaster, UK), ammonium ceric nitrate (Aldrich, UK), cobalt(II) chloride hexahydrate (E. Merck, India), and glacial acetic acid (E. Merck, India) were purchased and used as received. All the other reagents and solvents are of Analytical grade (A.R. grade) and were purchased from commercial sources and used as received.

2.1b General synthesis of compounds: Cobalt(III) complexes were synthesized by mixing phen $(0.198 \mathrm{~g}$, $1 \mathrm{mmol}), \mathrm{CoCl}_{2} \cdot 6 \mathrm{H}_{2} \mathrm{O}(0.237 \mathrm{~g}, 1 \mathrm{mmol})$ and ceric ammonium nitrate in $1: 1: 2$ ratio. For the synthesis of $[1] \mathrm{NO}_{3} \cdot 3 \mathrm{H}_{2} \mathrm{O}, 4 / 6(\mathrm{v} / \mathrm{v}) \mathrm{AcOH}: \mathrm{H}_{2} \mathrm{O}(7 \mathrm{~N})$ has been used as solvent mixture, whereas for $[1] \mathrm{NO}_{3}$. $\mathrm{CH}_{3} \mathrm{CO}_{2} \mathrm{H} \cdot \mathrm{H}_{2} \mathrm{O}$, we used 7/3 (v/v) AcOH: $\mathrm{H}_{2} \mathrm{O}(12 \mathrm{~N})$. The reaction mixture was kept on magnetic stirrer for another 30 mins. The dark brown supernatant liquids were kept in air for slow evaporation. After 15-20 days the fine microcrystalline compounds were separated out, washed in hexane and dried in vacuo over silica gel indicator. The spectroscopic measurements and elemental analyses confirm the structural formation of the complexes. Yield of $[\mathbf{1}] \mathrm{NO}_{3} \cdot 3 \mathrm{H}_{2} \mathrm{O}$ (based on metal salt): $0.3180 \mathrm{~g}(73.1 \%)$. Anal cal. for $\mathrm{C}_{24} \mathrm{H}_{22} \mathrm{~N}_{5} \mathrm{Cl}_{2} \mathrm{O}_{6} \mathrm{Co}: \mathrm{C}, 47.54 ; \mathrm{H}, 3.66 ; \mathrm{N}, 11.55$; Found: C, 47.45; H, 3.58; N, 11.59. Selected IR bands ( $\mathrm{KBr}$ pellet, $\mathrm{cm}^{-1}$ ): 3417 (s), 1384 (s), 1426 (m), 1604 (s). UV-Vis $(\lambda, \mathrm{nm})$ : 232, 265, 450-650 (broad band). Yield of [1] $\mathrm{NO}_{3} \cdot \mathrm{CH}_{3} \mathrm{CO}_{2} \mathrm{H} \cdot \mathrm{H}_{2} \mathrm{O}$ (based on metal salt): $0.3060 \mathrm{~g}(70.3 \%)$. Anal cal. for $\mathrm{C}_{26} \mathrm{H}_{22} \mathrm{~N}_{5} \mathrm{Cl}_{2} \mathrm{O}_{6} \mathrm{Co}: \mathrm{C}$, 49.54; H, 3.52; N, 11.11; Found: C, 49.43; H, 3.43; N, 11.18. Selected IR bands (KBr pellet, $\left.\mathrm{cm}^{-1}\right): 3401(\mathrm{~s})$, 1383 (s), 1424 (m), 1609 (s). UV-Vis ( $\lambda$, nm): 233, 267, 450-650 (broad band).

\subsection{Physical measurements}

Infrared spectra $(\mathrm{KBr})$ were recorded with a FTIR8400S SHIMADZU spectrophotometer in the range 400-3600 $\mathrm{cm}^{-1}$. ${ }^{1} \mathrm{H}$ NMR spectra in DMSO- $d_{6}$ were obtained on a Bruker Avance $300 \mathrm{MHz}$ spectrometer at $25^{\circ} \mathrm{C}$ and was recorded at $299.948 \mathrm{MHz}$. Chemical shifts are reported with reference to $\mathrm{SiMe}_{4}$. Diffuse reflectance spectra were obtained with a Varian Cary $5 \mathrm{E}$ spectrometer using polytetrafluoroethylene (PTFE) as a reference. Ground state absorption was measured with a JASCO V-530 UV-vis spectrophotometer. Thermal analyses of the compounds were carried out on a PerkinElmer Diamond TG/DTA system up to $700^{\circ} \mathrm{C}$ in a static nitrogen atmosphere with a heating rate of $10^{\circ} \mathrm{C} / \mathrm{min}$. Elemental analyses were performed on a Perkin Elmer $2400 \mathrm{CHN}$ microanalyser. Electrospray ionization (ESI) mass spectrum was recorded using a Q-tof-micro-quadruple mass spectrometer.

\section{$2.3 X$ X-ray diffraction study}

Single crystal data of $[\mathbf{1}] \mathrm{NO}_{3} \cdot 3 \mathrm{H}_{2} \mathrm{O}$ and $[\mathbf{1}] \mathrm{NO}_{3} \cdot \mathrm{CH}_{3}$ $\mathrm{CO}_{2} \mathrm{H} \cdot \mathrm{H}_{2} \mathrm{O}$ were collected on a Bruker SMART APEX II CCD diffractometer using $\mathrm{Mo}-\mathrm{K}_{\alpha}$ radiation $(\lambda=$ $0.71073 \AA$ ) at 220 and $150 \mathrm{~K}$ respectively. Systematic absent reflections led to the identification of identical space group $\mathrm{Cc}(9)$ for $[\mathbf{1}] \mathrm{NO}_{3} \cdot 3 \mathrm{H}_{2} \mathrm{O}$ and [1] $\mathrm{NO}_{3} \cdot \mathrm{CH}_{3} \mathrm{CO}_{2} \mathrm{H} \cdot \mathrm{H}_{2} \mathrm{O}$ crystals. Of the 9452 and 6018 total reflections for the two respective complexes 4708 and 2421 with $\mathrm{I}>2 \sigma$ were used for structure solutions. The structures were solved by direct methods, and the structure solution and refinement were based on $|F|^{2}$. All non-hydrogen atoms were refined with anisotropic displacement parameters whereas hydrogen atoms were placed in calculated positions when possible and given isotropic $U$ values 1.2 times that of the atom to which they are bonded. Fourier map showed the maximum and minimum peak heights at $0.40,-0.35$ for $[1] \mathrm{NO}_{3} \cdot 3 \mathrm{H}_{2} \mathrm{O}$ 
and 0.25 and -0.26 for $[1] \mathrm{NO}_{3} \cdot \mathrm{CH}_{3} \mathrm{CO}_{2} \mathrm{H} \cdot \mathrm{H}_{2} \mathrm{O}$ with no chemical significance. All calculations were carried out using Bruker programs ${ }^{23}$ and SHELXL-97. ${ }^{24}$

\subsection{Catalytic oxidation of 3,5-DTBC}

In order to examine the catecholase activity of the complex, a $10^{-4} \mathrm{M}$ solution of $[\mathbf{1}]^{+}$in methanol solvent was treated with 100 equiv. of 3,5-ditert-butylcatechol (3,5-DTBC) under aerobic conditions at room temperature. Absorbance $v s$. wavelength (wavelength scans) of the solution was recorded at a regular time intervals of $5 \mathrm{~min}$ in the wavelength range $300-500 \mathrm{~nm}$ for up to $60 \mathrm{~min}$. It may be noted here that a blank experiment without catalyst does not show formation of the quinone up to $6 \mathrm{~h}$ in $\mathrm{MeOH}$.

To determine the dependence of rate on substrate concentration and various kinetic parameters, a $10^{-4} \mathrm{M}$ solution of the complex was treated with at least 10 equiv. of substrate to maintain the pseudo- first order condition. The reaction was followed spectrophotometrically by monitoring the increase in the absorbance at $398 \mathrm{~nm}$ (Quinone band maxima) as a function of time (time scan) up to $60 \mathrm{~min}$.

\subsection{DNA cleavage studies}

Cleavage of pBR 322 DNA by $[1]^{+}$was monitored by agarose gel electrophoresis technique. The complex $(25,50,75$ and $100 \mu \mathrm{g})$ solutions were incubated with plasmid DNA for an hour at $37^{\circ} \mathrm{C}$. After incubation $2 \mu 1$ of bromophenol blue dye was mixed with [1] ${ }^{+}$and loaded carefully into the electrophoresis chamber wells along with the control DNA. TAE buffer was used as a running buffer and $[\mathbf{1}]^{+}$is stable in this buffer medium. The plasmid DNA, thus treated, was loaded on agarose gel and constant $50 \mathrm{~V}$ was applied for $30 \mathrm{~min}$. Then the bands were stained with EB and observed in the gel documentation system and photographed to determine the extent of DNA cleavage and the results are compared with the control.

To confirm the cleavage activity of the $[1]^{+}$, UV spectroscopic analysis was performed. $1 \mu \mathrm{L}$ of the DNA was diluted with $50 \mu \mathrm{L}$ of TE buffer and absorbance was read at $260 \mathrm{~nm}$ for the control DNA, along with the test samples containing different concentrations of $[\mathbf{1}]^{+}$and the DNA. The concentration of the DNA was calculated using the formula:

DNA concentration $(\mu \mathrm{g} / \mathrm{mL})=(\mathrm{OD} 260) \times($ dilution factor $) \times(50 \mu \mathrm{g} \mathrm{DNA} / \mathrm{mL}) /(\mathrm{OD} 260$ unit $)$

\subsection{Anti-cancer activity of the $[1]^{+}$complex}

2.6a Cell culture: The human hepatocarcinoma (HepG2) cell line was obtained from the National Centre for Cell Science (NCCS), Pune, India. The cells were cultured in DMEM medium (Sigma-Aldrich, St. Louis, MO, USA), supplemented with $10 \%$ fetal bovine serum (Gibco) and $100 \mathrm{U} / \mathrm{mL}$ of penicillin and $100 \mu \mathrm{g} / \mathrm{mL}$ of streptomycin as antibiotics (Gibco), in 96 well culture plates, at $37^{\circ} \mathrm{C}$, in a humidified atmosphere of $5 \% \mathrm{CO}_{2}$, in a $\mathrm{CO}_{2}$ incubator (Forma, Thermo Scientific, USA). All experiments were performed using cells from passage 15 or less.

2.6b Cytotoxicity assay (MTT assay): The Co(III) complex, $[1]^{+}$in the concentration range $50-500 \mu \mathrm{M}$ was dissolved in DMSO and $[1]^{+}$is stable in this medium. It was added to the wells $24 \mathrm{~h}$ after seeding of $5 \times 10^{3}$ cells per well in $200 \mu \mathrm{L}$ of fresh culture medium. DMSO solution was used as the solvent control. A miniaturized viability assay using 3-(4,5-dimethylthiazol-2-yl)-2,5diphenyl-tetrazolium bromide (MTT) was carried out according to the method described by Mosmann. ${ }^{25}$ After 24 and $48 \mathrm{~h}, 20 \mu \mathrm{L}$ of MTT solution $[5 \mathrm{mg} / \mathrm{mL}$ in phosphate-buffered saline (PBS)] was added to each well and the plates were wrapped with aluminum foil and incubated for $4 \mathrm{~h}$ at $37^{\circ} \mathrm{C}$. The purple formazan product was dissolved by addition of $100 \mu \mathrm{L}$ of DMSO to each well. The absorbance was monitored at $570 \mathrm{~nm}$ (measurement) and $630 \mathrm{~nm}$ (reference) using a 96-well plate reader (Bio-Rad, Hercules, CA, USA). Data were collected for three replicates each and used to calculate the mean. The percentage inhibition was calculated, from this data, using the formula:

\footnotetext{
$=\underline{\text { Mean OD of untreated cells (control) }- \text { Mean OD of treated cells }(\text { treat }) \times 100}$ Mean absorbance of untreated cells (control)
}

From these data, the $\mathrm{IC}_{50}$ (the concentration at which $[1]^{+}$killed $50 \%$ of the cells at the respective durations of treatment) for 24 and $48 \mathrm{~h}$ treatment were arrived at.

2.6c Acridine orange (AO) and ethidium bromide $(E B)$ staining: Acridine orange and ethidium bromide staining was performed as described by Spector et al. ${ }^{26}$ The cell suspension of each sample containing $5 \times 10^{5}$ cells, was treated with $25 \mu \mathrm{L}$ of AO and EB solution (3.8 $\mu \mathrm{M}$ of AO and $2.5 \mu \mathrm{M}$ of EB in PBS) and examined in a fluorescent microscope (Carl Zeiss, Germany) using an UV filter (450-490 nm). Three hundred cells per sample were counted in triplicate for each dose point. The cells were scored as viable, apoptotic or necrotic as judged by the staining, nuclear morphology and membrane integrity ${ }^{26}$ and the percentages of apoptotic and necrotic cells were then calculated. Morphological changes were also observed and photographed. 
2.6d Hoechst 33528 Staining: The Human Hepatocarcinoma (HepG@) cells were cultured in 6-well plates and treated with $\mathrm{IC}_{50}$ concentration of $[1]^{+}$. After $24 \mathrm{~h}$ incubation, the treated and untreated cells were harvested and stained with Hoechst $33258(1 \mathrm{mg} / \mathrm{mL}$, aqueous) for $5 \mathrm{~min}$ at room temperature. A drop of cell suspension was placed on a glass slide, and a cover slip was laid over to reduce light diffraction. At random 300 cells, in duplicate, were observed at $\times 400$ in a fluorescent microscope (Carl Zeiss, Jena, Germany) fitted with a 377-355 nm filter, and the percentage of cells reflecting pathological changes was calculated.

\subsection{Thermogravimetric analysis}

The thermal behaviour of the complexes $[1] \mathrm{NO}_{3} \cdot 3 \mathrm{H}_{2} \mathrm{O}$ and [1] $\mathrm{NO}_{3} \cdot \mathrm{CH}_{3} \mathrm{CO}_{2} \mathrm{H} \cdot \mathrm{H}_{2} \mathrm{O}$ were followed up to $700^{\circ} \mathrm{C}$ in a static nitrogen atmosphere with a heating rate of $10^{\circ} \mathrm{C}$ per minute.

\section{Results and Discussion}

\subsection{Syntheses and formulation}

The mononuclear cobalt(III) complexes, $[1] \mathrm{NO}_{3} \cdot 3 \mathrm{H}_{2} \mathrm{O}$ and [1] $\mathrm{NO}_{3} \cdot \mathrm{CH}_{3} \mathrm{CO}_{2} \mathrm{H} \cdot \mathrm{H}_{2} \mathrm{O}$ were prepared by addition of 1,10-phenanthroline to a solution of $\mathrm{CoCl}_{2} \cdot 6 \mathrm{H}_{2} \mathrm{O}$ followed by the addition of solid CAN in aqueous acetic acid solution (v/v) at different $\mathrm{pH}$ for both complexes at room temperature, respectively. Interestingly, different composition of solvent mixture produces different solvate molecules with identical Co(III)-coordination linkages. The schematic presentation of syntheses is given below (Scheme 1):

\subsection{Spectroscopic characterization and solution properties}

Two isostructural $\mathrm{Co}$ (III) complexes, $\left[\mathrm{Co}(\text { phen })_{2} \mathrm{Cl}_{2}\right.$ ] $\mathrm{NO}_{3} \cdot 3 \mathrm{H}_{2} \mathrm{O}$ and $\left[\mathrm{Co}(\text { phen })_{2} \mathrm{Cl}_{2}\right] \mathrm{NO}_{3} \cdot \mathrm{CH}_{3} \mathrm{CO}_{2} \mathrm{H} \cdot \mathrm{H}_{2} \mathrm{O}$ were prepared by addition of 1,10-phen to a solution of $\mathrm{CoCl}_{2} \cdot 6 \mathrm{H}_{2} \mathrm{O}$ followed by the addition of solid $\mathrm{CAN}$ in aqueous acetic acid solutions having two different acetic acid concentrations. However, such compounds could not be prepared in other mixed aqueous solvents like methanol-water, acetonitrilewater, dichloromethane-water or in pure solvents like water and methanol. Here, CAN is used to oxidize the metal ion at +3 oxidation level and it also supplies heavier nitrate anion to stabilize the complexes. The $\left[\mathrm{Co}(\mathrm{phen})_{2} \mathrm{Cl}_{2}\right]^{+}$is soluble in all the common solvents like methanol, acetonitrile, water, etc.

The IR spectra of $[1] \mathrm{NO}_{3} \cdot 3 \mathrm{H}_{2} \mathrm{O}$ and $[1] \mathrm{NO}_{3}$. $\mathrm{CH}_{3} \mathrm{CO}_{2} \mathrm{H} \cdot \mathrm{H}_{2} \mathrm{O}$ contain characteristic strong bands for the $\mathrm{NO}_{3}^{-}$anion at $\sim 1384 \mathrm{~cm}^{-1}$. These bands are overlapped with a set of bands for the 1,10-phen fragment, which, in turn, also shows bands at about 1000 and 3100 $\mathrm{cm}^{-1} \cdot{ }^{27}$ Bands characteristic for the $\alpha$-diimine ligands are clearly observed at $\sim 1600 \mathrm{~cm}^{-1}$. Water molecules in the structure of the complexes were detected in the IR spectra by a broad band centred at about 3401 and $3417 \mathrm{~cm}^{-1}$.

The diffuse reflectance spectra of the cobalt(III) complexes exhibit three regions: three absorption bands in the UV region, corresponding to the intra-ligand and ligand-to-metal transitions of 1,10-phen, a second range from about 450 to $650 \mathrm{~nm}$ and a third weak band centred at about $800 \mathrm{~nm}$ (figure S1). The latter two bands originate from the same $d-d$ transitions. ${ }^{28}$

NMR spectroscopy experiments on $[1] \mathrm{NO}_{3} \cdot 3 \mathrm{H}_{2} \mathrm{O}$ and $[1] \mathrm{NO}_{3} \cdot \mathrm{CH}_{3} \mathrm{CO}_{2} \mathrm{H} \cdot \mathrm{H}_{2} \mathrm{O}$ testify to its diamagnetic nature. The ${ }^{1} \mathrm{H}$ NMR spectra of the complexes contain four doublet peaks at $\sim 10.03,9.31,8.82$ and $8.38 \mathrm{ppm}$, and two triplet peaks at $\sim 8.5$ and $7.6 \mathrm{ppm}$ (figure $\mathrm{S} 2$ ) for the 1,10-phenanthroline ligands with characteristic coupling constants ${ }^{3} J_{\mathrm{H}, \mathrm{H}}=7.66-7.53 \mathrm{~Hz}$.

In order to probe the solution stability of the complexes, we have performed UV-Vis spectral measurements for methanolic solution of $[1] \mathrm{NO}_{3} \cdot 3 \mathrm{H}_{2} \mathrm{O}$ and [1] $\mathrm{NO}_{3} \cdot \mathrm{CH}_{3} \mathrm{CO}_{2} \mathrm{H} \cdot \mathrm{H}_{2} \mathrm{O}$ at room temperature and both the compounds produced almost identical band at 232, 267, 341 and $540 \mathrm{~nm}$. Low intensity and broad transitions at $540 \mathrm{~nm}$ are attributed to ligand field bands in $\mathrm{Co}^{\mathrm{III}}$ octahedral field (figure S3) and these bands remained unaffected over a period of at least 5 days revealing that the complexes are stable in solution at room temperature. Mass spectral analysis of the cobalt complexes further consolidates this fact by producing molecular ion peak at $\mathrm{m} / \mathrm{z} 489.0263$ (Calc. 489.0084) (figure S4) in methanol and this experimental peak corresponds to the existence of the stable cationic species as $\left[\mathrm{Co}(1,10 \text {-phen })_{2} \mathrm{Cl}_{2}\right]^{+}$in solution.

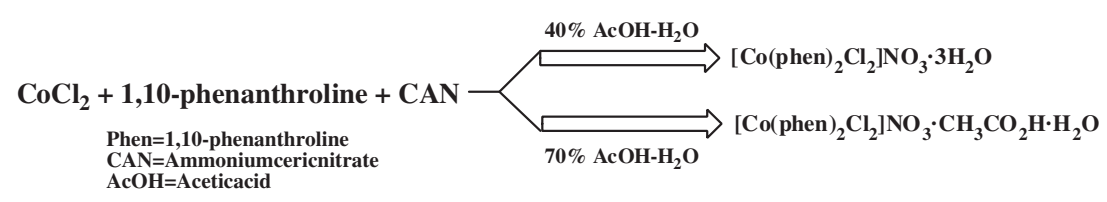

Scheme 1. Preparation of cobalt(III) complexes. 

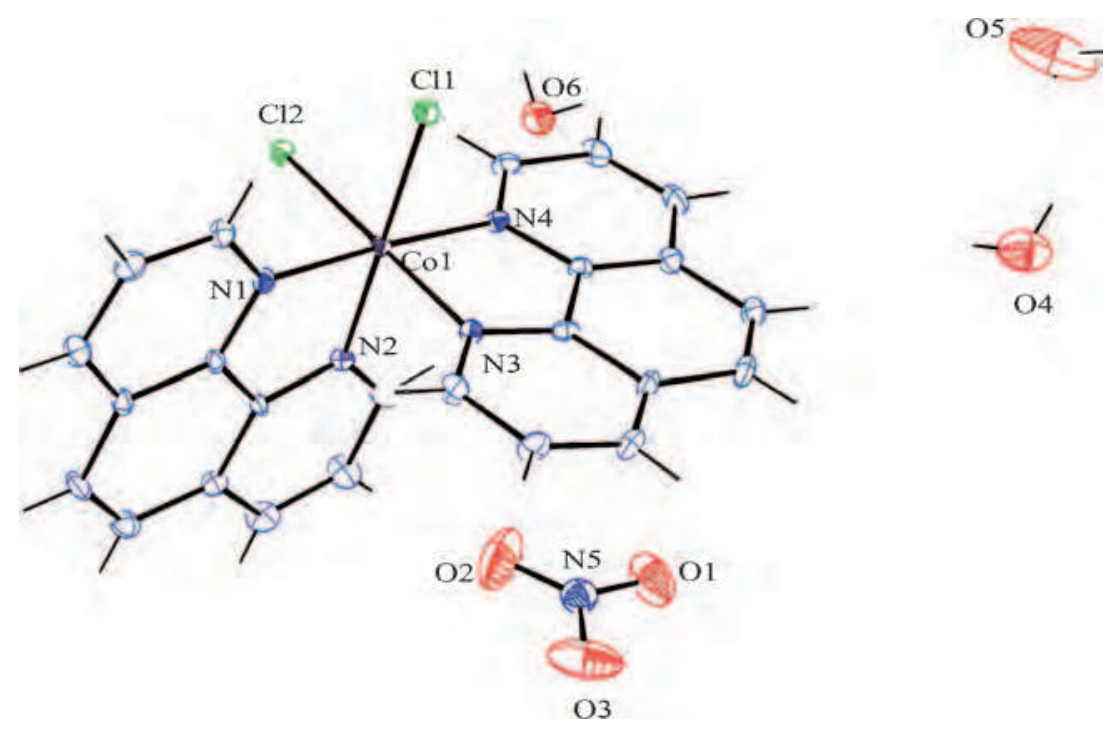

Figure 1. ORTEP diagram of $[\mathbf{1}] \mathrm{NO}_{3} \cdot 3 \mathrm{H}_{2} \mathrm{O}(30 \%$ ellipsoid probability) with atom numbering scheme.

\subsection{Description of crystal structures}

The single crystal X-ray diffraction analysis reveals that both the crystal lattices of $[1] \mathrm{NO}_{3} \cdot 3 \mathrm{H}_{2} \mathrm{O}$ and [1] $\mathrm{NO}_{3} \cdot \mathrm{CH}_{3} \mathrm{CO}_{2} \mathrm{H} \cdot \mathrm{H}_{2} \mathrm{O}$ consist of identical mononuclear cationic unit $\left[\mathrm{Co}(\text { phen })_{2} \mathrm{Cl}_{2}\right]^{+}$but differ in inclusion of solvent molecules. The ORTEP diagram with atom numbering scheme of the mononuclear complexes [1] $\mathrm{NO}_{3} \cdot 3 \mathrm{H}_{2} \mathrm{O}$ and $[1] \mathrm{NO}_{3} \cdot \mathrm{CH}_{3} \mathrm{CO}_{2} \mathrm{H} \cdot \mathrm{H}_{2} \mathrm{O}$ are shown in figures 1 and 2 . The coordination geometry around each (III) centre is best described as distorted octahedron with a $\mathrm{CoN}_{4} \mathrm{Cl}_{2}$ chromophore. The coordination includes two coordinated phenanthroline ligands, along with two coordinated $\mathrm{Cl}$ atoms in mutual cis orientation in $[1] \mathrm{NO}_{3} \cdot 3 \mathrm{H}_{2} \mathrm{O}$ and $[1] \mathrm{NO}_{3} \cdot \mathrm{CH}_{3} \mathrm{CO}_{2} \mathrm{H} \cdot \mathrm{H}_{2} \mathrm{O}$. The angles $92.15(4)^{\circ}$ and $91.89(3)^{\circ}$ between the two coordinated chlorine atoms around $\mathrm{Co}$ (III) centre in $[1] \mathrm{NO}_{3} \cdot 3 \mathrm{H}_{2} \mathrm{O}$ and $[1] \mathrm{NO}_{3} \cdot \mathrm{CH}_{3} \mathrm{CO}_{2} \mathrm{H} \cdot \mathrm{H}_{2} \mathrm{O}$ as $\mathrm{Cl}(1)-\mathrm{Co}(1)-\mathrm{Cl}(2)$ indicate the cisoid representation of the structures. A summary of the crystallographic data and structure refinement parameters is given in table 1 . The bond angle and bond distance data are given in table $\mathrm{S} 1$ for $[\mathbf{1}] \mathrm{NO}_{3} \cdot 3 \mathrm{H}_{2} \mathrm{O}$ and table $\mathrm{S} 2$ for $[1] \mathrm{NO}_{3} \cdot \mathrm{CH}_{3} \mathrm{CO}_{2} \mathrm{H} \cdot \mathrm{H}_{2} \mathrm{O}$.

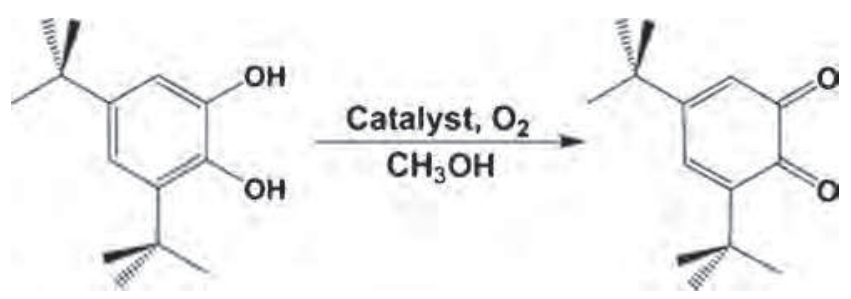

Scheme 2. Catalytic Oxidation of 3,5-DTBC to 3,5-DTBQ in air-saturated methanol solvent.

\subsection{Catecholase activity of $[1]^{+}$}

Catechol oxidases are type III copper proteins which catalyze the oxidation of catechols to quinones in the presence of oxygen. ${ }^{29}$ The catecholase activity of the $\left[\mathrm{Co}(\text { phen })_{2} \mathrm{Cl}_{2}\right]^{+}$complex, $[\mathbf{1}]^{+}$was studied using 3,5-di-tert-butylcatechol (3,5-DTBC) as a convenient model substrate, in air-saturated methanol solvent at room temperature $\left(25^{\circ} \mathrm{C}\right)$. For this purpose, a $1 \times 10^{-4} \mathrm{M}$ solution of this complex was treated with $1 \times 10^{-2} \mathrm{M}$ (100 equiv.) of 3,5-DTBC and the course of the reaction was followed by recording the UV-vis spectra of the mixture at an interval of $5 \mathrm{~min}$ for $1 \mathrm{~h}$ (Scheme 2).

Spectral bands at 232, 267, 341 and $540 \mathrm{~nm}$ appeared in the electronic spectrum of complex $[\mathbf{1}]^{+}$in methanol, whereas 3,5-DTBC showed a single band at $284 \mathrm{~nm}$. As the reaction proceeded, there was a gradual decrease in intensity of the band at $284 \mathrm{~nm}$ due to the catechol ${ }^{30}$ and an initial new band was formed at $\sim 398 \mathrm{~nm}$ (figure 3), which indicated the formation of the respective quinone derivative and the band maximum was gradually shifted to $398 \mathrm{~nm}$. 3,5-DTBQ was purified by column chromatography and isolated in high yield $(76.2 \%$ for 1$)$ by slow evaporation of the eluant. The product was identified by ${ }^{1} \mathrm{H}$ NMR spectroscopy. ${ }^{1} \mathrm{H}$ NMR $\left(\mathrm{CDCl}_{3}, 400\right.$ MHz) $\delta_{\mathrm{H}}: 1.15(\mathrm{~s}, 9 \mathrm{H}), 1.20(\mathrm{~s}, 9 \mathrm{H}), 6.15(\mathrm{~d}, J=2.4$ $\mathrm{Hz}, 1 \mathrm{H}), 6.86(\mathrm{~d}, J=2.4 \mathrm{~Hz}, 1 \mathrm{H})$.

Kinetic studies were performed to understand the extent of the efficiency. The kinetics of oxidation of 3,5DTBC were determined by the method of initial rates and involved monitoring the growth of the quinone band at $398 \mathrm{~nm}$ as a function of time. ${ }^{31}$ For this purpose, 0.04 $\mathrm{mL}$ of the complex solution, with a constant concentration of $1 \times 10^{-4} \mathrm{M}$, was added to $2 \mathrm{~mL}$ of 3,5-DTBC 

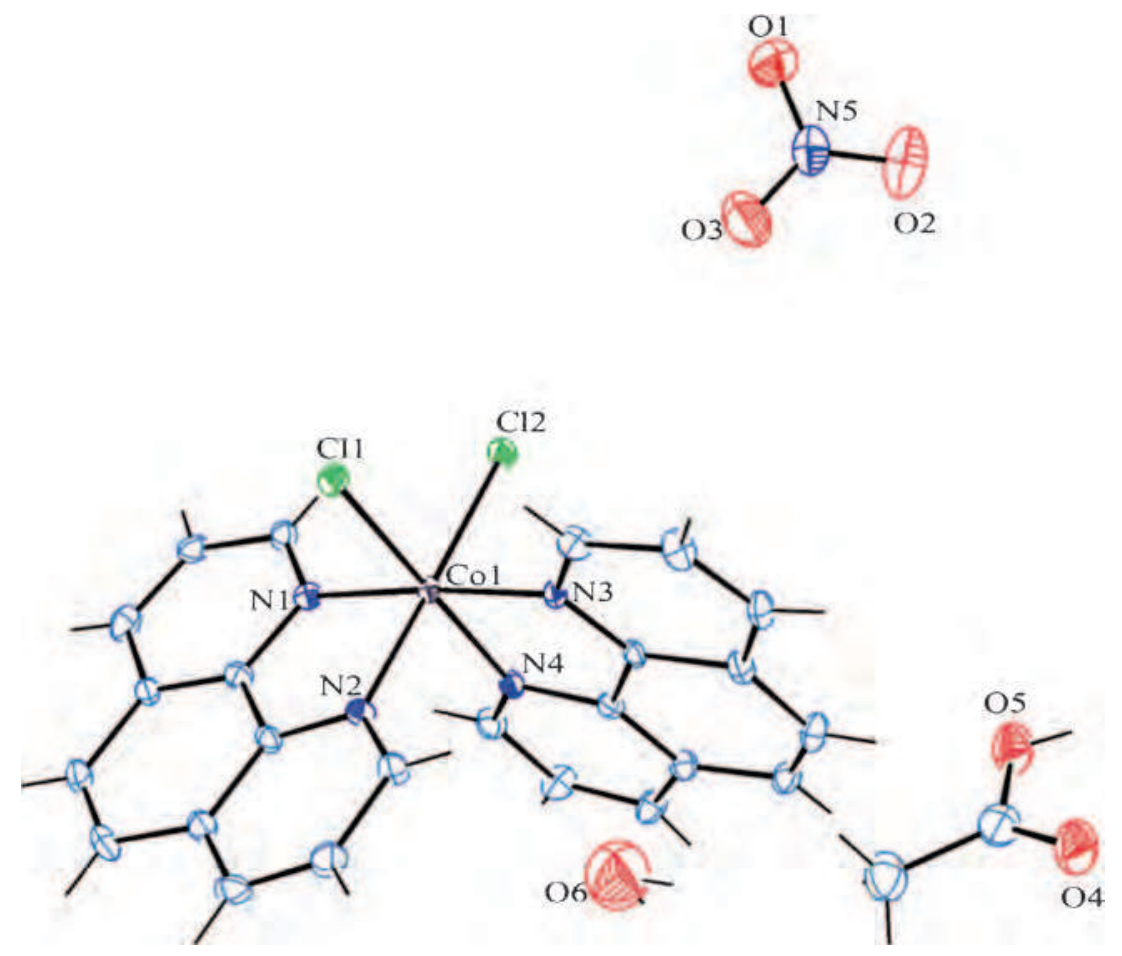

Figure 2. ORTEP diagram of $[\mathbf{1}] \mathrm{NO}_{3} \cdot \mathrm{CH}_{3} \mathrm{CO}_{2} \mathrm{H} \cdot \mathrm{H}_{2} \mathrm{O}$ (30\% ellipsoid probability) with atom numbering scheme.

Table 1. Crystal data and structure refinement parameters for $[1] \mathrm{NO}_{3} \cdot 3 \mathrm{H}_{2} \mathrm{O}$ and $[1] \mathrm{NO}_{3} \cdot \mathrm{CH}_{3} \mathrm{CO}_{2} \mathrm{H} \cdot \mathrm{H}_{2} \mathrm{O}$.

\begin{tabular}{lcc}
\hline Parameters & {$[\mathbf{1}] \mathrm{NO}_{3} \cdot 3 \mathrm{H}_{2} \mathrm{O}$} & {$[\mathbf{1}] \mathrm{NO}_{3} \cdot \mathrm{CH}_{3} \mathrm{CO}_{2} \mathrm{H} \cdot \mathrm{H}_{2} \mathrm{O}$} \\
Empirical formula & $\mathrm{C}_{24} \mathrm{H}_{22} \mathrm{~N}_{5} \mathrm{Cl}_{2} \mathrm{O}_{6} \mathrm{Co}$ & $\mathrm{C}_{26} \mathrm{H}_{22} \mathrm{~N}_{5} \mathrm{Cl}_{2} \mathrm{O}_{6} \mathrm{Co}$ \\
Formula weight & 606.30 & 630.32 \\
Temperature $(\mathrm{K})$ & $220(2)$ & $150(2)$ \\
Crystal system & Monoclinic & Monoclinic \\
Space group & $\mathrm{Cc}(9)$ & $\mathrm{Cc}(9)$ \\
$\mathrm{a}(\AA)$ & $15.2063(15)$ & $15.3215(9)$ \\
$\mathrm{b}(\AA)$ & $13.4762(13)$ & $13.3189(17)$ \\
$\mathrm{c}(\AA)$ & $12.3354(12)$ & $12.8357(17)$ \\
Volume $\left(\AA^{3}\right)$ & $2501.5(4)$ & $2578.0(6)$ \\
$\mathrm{Z}$ & 4 & 4 \\
$\rho\left(\mathrm{gcm}^{-3}\right)$ & 1.610 & 1.624 \\
$\mu\left(\mathrm{mm}^{-1}\right)$ & 0.951 & 0.927 \\
$\mathrm{~F}(000)$ & 1240 & 1288 \\
$\theta$ ranges $\left({ }^{\circ}\right)$ & $2.0-28.3$ & $2.0-25.0$ \\
$\mathrm{R}_{\text {int }}$ & 0.014 & 0.016 \\
$\mathrm{R}(\mathrm{reflections})$ & 9452 & 6018 \\
wR2 (reflections) & 4708 & 2421 \\
Final R indices & $0.0280,0.0799$ & $0.0293,0.0852$ \\
Largest peak and hole $\left(\mathrm{eA}^{\circ-3}\right)$ & $0.40,-0.35$ & $0.25,-0.26$ \\
\hline
\end{tabular}

of a particular concentration (varying its concentration from $1 \times 10^{-3} \mathrm{M}$ to $1 \times 10^{-2} \mathrm{M}$ ) to achieve the ultimate concentration of the complex as $1 \times 10^{-4} \mathrm{M}$. The colour of the solution gradually turned deep brown, indicating the gradual conversion of 3,5-DTBC to 3,5-DTBQ. The experiments were done at a constant temperature of $25^{\circ} \mathrm{C}$ under aerobic conditions. For a particular complexsubstrate mixture, time scan at the maximum of the quinone band (398 $\mathrm{nm}$ ) was carried out for a period of $60 \mathrm{~min}$. The rate constants versus concentration of the substrate data were then analyzed on the basis of the Michaelis-Menten approach of enzymatic kinetics to get the Lineweaver-Burk plot (double reciprocal), as well as the values of the parameters $\mathrm{V}_{\max }, \mathrm{K}_{\mathrm{m}}$, and $\mathrm{K}_{\text {cat }}$. The observed rate constant versus substrate concentration plot and the Lineweaver-Burk plot for complex 


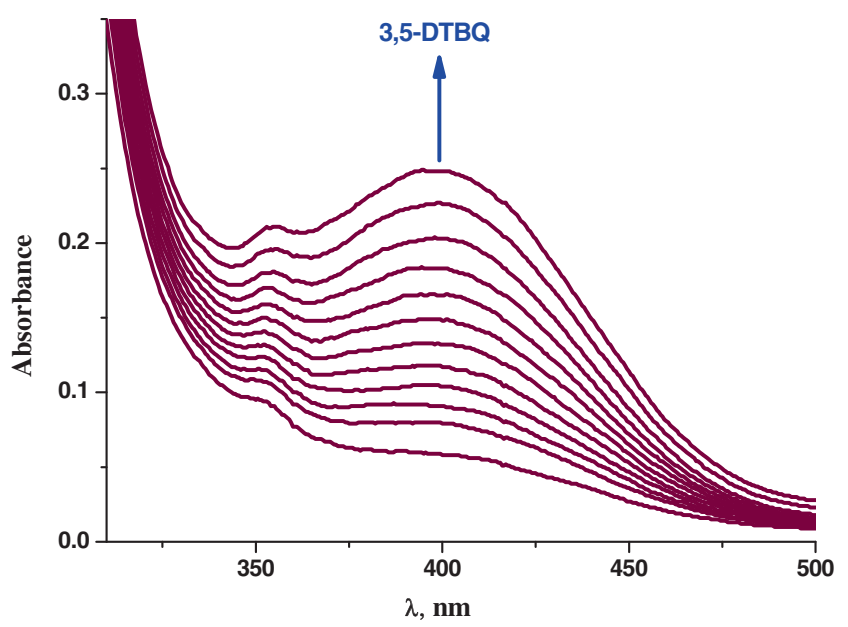

Figure 3. Increase of quinone band at $398 \mathrm{~nm}$ after addition of 100 equivalents of 3,5 -DTBC to a solution containing $[1]^{+}\left(10^{-4} \mathrm{M}\right)$ in methanol at $25^{\circ} \mathrm{C}$. The spectra were recorded after every $5 \mathrm{~min}$.

$[1]^{+}$in $\mathrm{MeOH}$ is shown in figure 4. To reveal high catalytic activity of $[\mathbf{1}]^{+}$, we drew a comparison between our cobalt(III) complex and some other mono- and polynuclear cobalt complexes. ${ }^{32-35}$ The data obtained from the Lineweaver-Burk plot model were used for a comparison of catalytic activity towards the oxidation of 3,5-DTBC as shown in table 2. The kinetic parameters of $[\mathbf{1}]^{+}$are also presented in table 2 . This comparison also indicates that $[\mathbf{1}]^{+}$acts as a better and effective catalyst towards catecholase activity than some recently reported ones. ${ }^{32-35}$

\subsection{Mechanistic aspects towards catalytic oxidation of 3,5-di-tert-butylcatechol $\left(\right.$ DTBC) by $[1]^{+}$}

Regarding complexes of metal ions of cobalt as active catalysts for catechol oxidase activity, two or three examples of mononuclear cobalt complexes are known in literature. ${ }^{15 b, c, 33}$ So, cobalt(III) compound, $[\mathbf{1}]^{+}$in the present investigation is one of the few examples of mononuclear cobalt complexes containing catalyst of catecholase activity for which both the single crystal Xray structure and $\mathrm{K}_{\mathrm{cat}}$ value has been determined. To get an insight into the nature of possible complex-substrate intermediates, ESI-MS positive spectra of a 1:100 mixture of $[\mathbf{1}]^{+}$and $3,5-\mathrm{DTBCH}_{2}$ were recorded after 20 min of mixing in methanol. The observed patterns are presented in figure S5 (Scheme 3).

Most importantly, characteristic peaks are observed at $\mathrm{m} / \mathrm{z}=243.55$ and 641.02 . The peaks at $\mathrm{m} / \mathrm{z}=243.55$ and 641.02 correspond, respectively, to the quinonesodium aggregate $[(3,5-\mathrm{DTBQ}) \mathrm{Na}]^{+}$and $\left[\mathrm{Co}^{\mathrm{II}}(1,10-\mathrm{phen})_{2}\right.$ $\left.\left(3,5-\mathrm{DTBC}^{2-}\right) \mathrm{H}\right]^{+}$. The latter peaking at $\mathrm{m} / \mathrm{z}=641.02$ is interesting because the peak position in the observed mass spectral pattern clearly indicates that the peak arises due to $1: 1$ complex-substrate aggregate $\left[\mathrm{Co}^{\mathrm{II}}(1,10-\text { phen })_{2}\left(3,5-\mathrm{DTBC}^{2-}\right) \mathrm{H}\right]^{+}$. It is logical to consider the dianionic $3,5-\mathrm{DTBCH}^{2-}$ species in $\mathrm{CO}^{\mathrm{II}}(1,10$ phen $\left.)_{2}\left(3,5-\mathrm{DTBC}^{2-}\right) \mathrm{H}\right]^{+}$as coordinated in bidentate chelating mode through the phenolate oxygen atom to the cobalt(III) centre. The intermediate $\mathrm{Co}$ (III) complex is reduced to $\mathrm{Co}$ (II) by the catechol derivative, and 3,5DTBC itself gets oxidised to quinone in presence of oxygen with the production of water.

Whatever the aftermath, coordination of the catechol moiety to the metal centre is an essential requirement for a complex to show catecholase activity. In the two proposed mechanisms regarding the in vivo cycle, 1:1 adduct formation between a dicopper(II) core and the substrate has been mentioned. While monodentate asymmetric coordination of the substrate has been proposed in one mechanism (Krebs's mechanism), ${ }^{17, \mathrm{~d}}$ simultaneous coordination of the substrate to both copper centres in the dinucleating bridging is suggested in the second (Solomon's mechanism). ${ }^{17 b}$ Although our cationic mononuclear cobalt(III) complex is not a $\mathrm{Cu}^{\mathrm{II}} \mathrm{Cu}^{\mathrm{II}}$ molecular system, one 1:1 complex substrate aggregate $\left[\mathrm{Co}^{\mathrm{II}}(1,10-\text { phen })_{2}\left(3,5-\mathrm{DTBC}^{2-}\right) \mathrm{H}\right]^{+}$having a bidentate chelating catechol moiety in that aggregate has been identified in the ESI-MS positive spectrum in the present investigation. So, after comparing these data, it can be concluded that the reported cobalt(III) complex is quite an efficient catalyst and has an appreciable turnover rate in methanolic medium. Besides, $[1]^{+}$being a mononuclear cobalt(III) complex with noncopper centre is mimicking an enzyme with a dicopper active site.

\subsection{DNA cleavage studies}

The irradiation of pBR322 plasmid DNA in the presence of the $[\mathbf{1}]^{+}$was studied so as to determine the efficiency with which it sensitizes DNA cleavage. This can be achieved by monitoring the transition from the naturally occurring, covalently closed circular form (Form I) to the open circular relaxed form (Form II). This occurs when one of the strands of the plasmid is nicked, and can be determined by gel electrophoresis of the plasmid. Extended irradiation results in a build up of nicks on both strands of the plasmid, which eventually results in its opening to the linear form (Form III). When circular plasmid DNA is subjected to gel electrophoresis, relatively faster migration is observed in the supercoiled form (Form I). Form (II) migrates slowly and Form III migrates between Form II and Form I. ${ }^{36,37}$ 


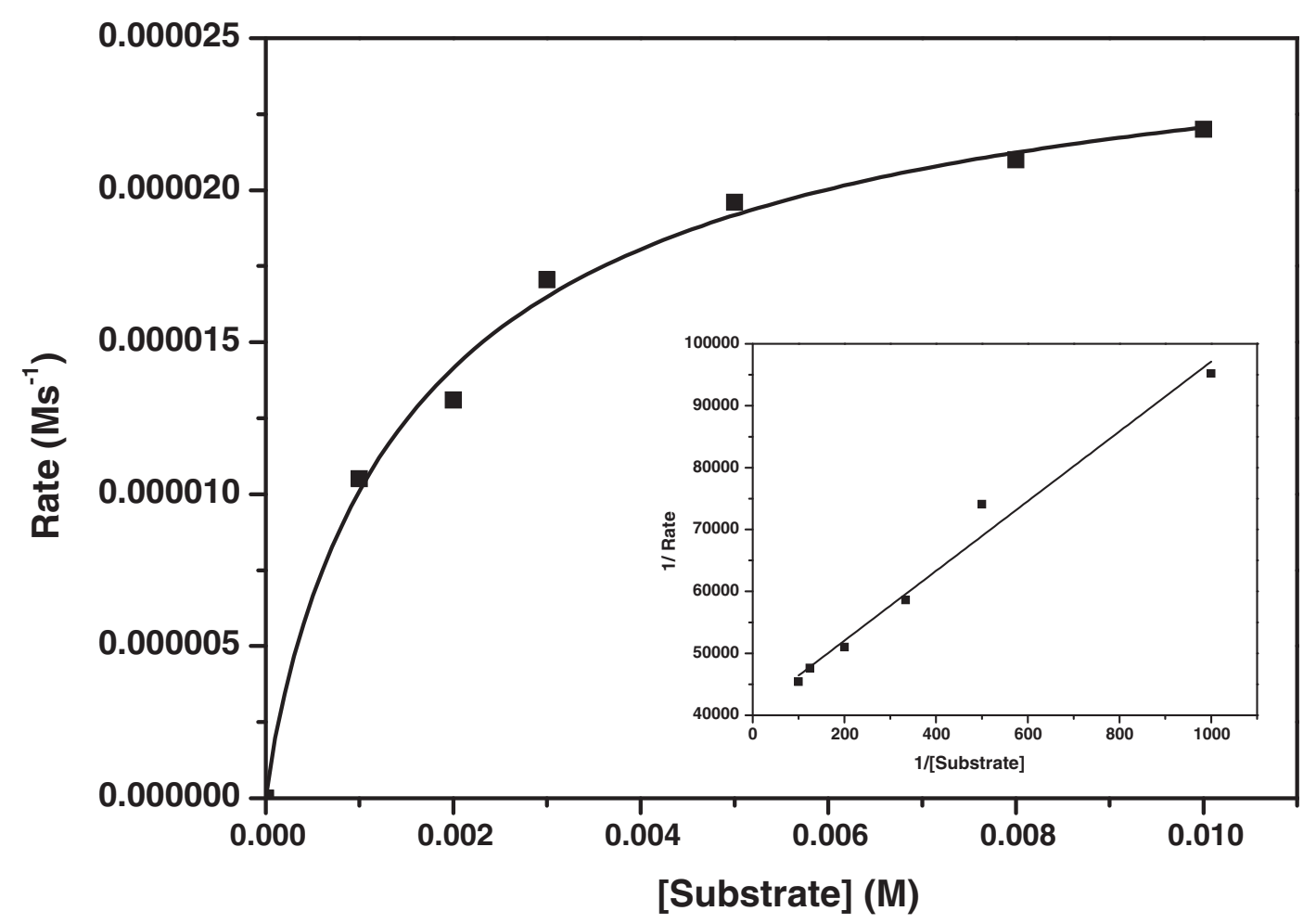

Figure 4. Plot of rate vs. [substrate] in presence of $[\mathbf{1}]^{+}$in $\mathrm{MeOH}$; inset: Lineweaver-Burk plot.

Table 2. Kinetic parameters for the oxidation of 3,5-DTBC catalyzed by [1] $]^{+}$in methanol.

\begin{tabular}{lccccc}
\hline Complex & Solvent & $\mathrm{V}_{\max }\left(\mathrm{M} \mathrm{s}^{-1}\right)$ & $\mathrm{K}_{\mathrm{m}}(\mathrm{M})$ & $\mathrm{K}_{\text {cat }}\left(\mathrm{h}^{-1}\right)$ & Reference \\
$*[\mathbf{1}]^{+}$ & $\mathrm{MeOH}$ & $2.68 \times 10^{-5}$ & $1.77 \times 10^{-3}$ & $9.65 \times 10^{2}$ & This paper \\
$\mathbf{1}$ & $\mathrm{MeOH}$ & $1.891 \times 10^{-5}$ & $1.57 \times 10^{-5}$ & $4.53 \times 10^{1}$ & 32 \\
$\mathbf{1}$ & $\mathrm{MeOH}$ & $3.36 \times 10^{-5}$ & $7.38 \times 10^{-4}$ & $1.21 \times 10^{3}$ & 33 \\
$\mathbf{1}$ & $\mathrm{MeCN}$ & $1.33 \times 10^{-5}$ & $8.70 \times 10^{-3}$ & $7.97 \times 10^{1}$ & 34 \\
$\mathbf{1}$ & $\mathrm{MeOH}$ & $7.23 \times 10^{-2}$ & $3.01 \times 10^{-6}$ & $4.82 \times 10^{2}$ & 32 \\
$\mathbf{1}$ & $\mathrm{MeOH}$ & $7.23 \times 10^{-2}$ & $7.23 \times 10^{-2}$ & $4.29 \times 10^{-2}$ & 35 \\
\hline
\end{tabular}

$*$ Std. Error for $\mathrm{V}_{\max }\left(\mathrm{MS}^{-1}\right)=4.11 \times 10^{-6}$; Std. Error for $\mathrm{K}_{\mathrm{m}}(\mathrm{M})=6.62 \times 10^{-4}$

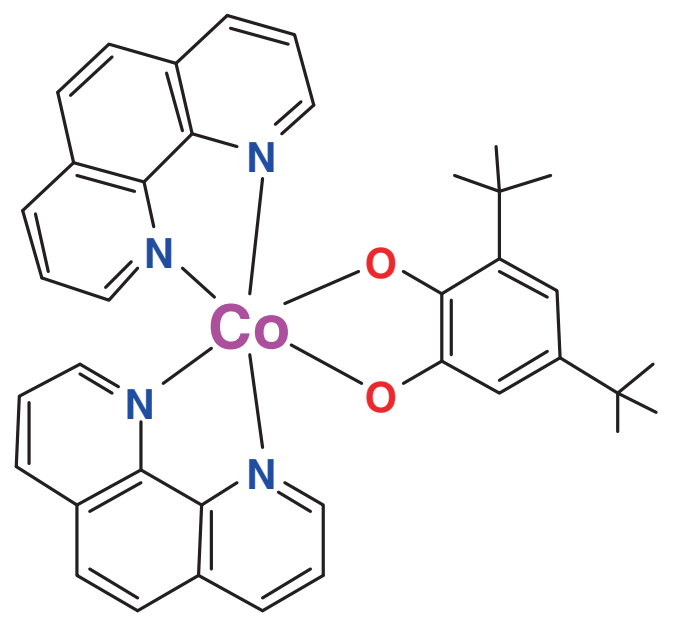

Scheme 3. Formation of mononuclear intermediate species during the course of catechol oxidation.
The ability of $[\mathbf{1}]^{+}$to cleave DNA was assayed with the aid of gel electrophoresis on pBR 322 DNA as the substrate in a medium of $5 \mathrm{mM}$ Tris- $\mathrm{HCl} / 50 \mathrm{mM} \mathrm{NaCl}$ buffer ( $\mathrm{pH} 7.1)$ in the absence of external additives. The DNA was mixed with different concentrations (25, 50,75 and $100 \mu \mathrm{g}$ ) of Co(III) complex and was incubated at $37^{\circ} \mathrm{C}$ for $1 \mathrm{~h}$. Figure 5 reveals the cleavage activity of $[1]^{+}$on pBR 322 DNA. Lane 1 shows the pBR 322 DNA control. Lane 2 shows the DNA treated with $25 \mu \mathrm{g}$ of complex $[1]^{+}$. There was a partial cleavage of the DNA with the addition of $25 \mu \mathrm{g}$ of the complex. Further addition of different concentrations (50, 75 and $100 \mu \mathrm{g}$ ) of the complex in Lane 3, Lane 4 , and Lane 5 did not show bands for the DNA. This finding clearly suggests that the concentration of the complex needed to cleave the pBR 322 DNA was $50 \mu \mathrm{g}$. 


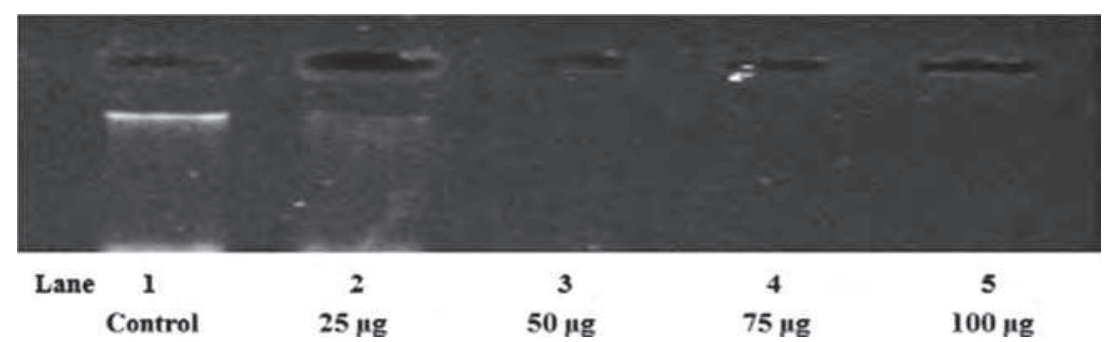

Figure 5. Concentration-dependent cleavage of plasmid pBR 322 DNA by $[1]^{+}$. Lane 1 shows the control DNA. Lane 2 shows DNA + sample $(25 \mu \mathrm{g})$; lane 3, DNA+ sample (50 $\mu \mathrm{g})$; lane 4, (75 $\mu \mathrm{g})$; lane 5, (100 $\mu \mathrm{g})$.

Table 3. UV Spectroscopic readings of pBR 322 DNA with $[1]^{+}$.

\begin{tabular}{lcc}
\hline Sample & Absorbance at 260 nm & Concentration of DNA \\
\hline Control pBR 322 DNA & 2.4 & $6 \mu \mathrm{g} / \mathrm{mL}$ \\
pBR 322 DNA + 25 $\mu \mathrm{g} \mathrm{[1]}]^{+}$ & 1.39 & $3.4 \mu \mathrm{g} / \mathrm{mL}$ \\
pBR 322 DNA + 50 $\mu \mathrm{g} \mathrm{[1]}]^{+}$ & 0.65 & $1.62 \mu \mathrm{g} / \mathrm{mL}$ \\
pBR 322 DNA + 75 $\mu \mathrm{g} \mathrm{[1]}{ }^{+}$ & 0.32 & $0.80 \mu \mathrm{g} / \mathrm{mL}$ \\
pBR 322 DNA + 100 $\mu \mathrm{g} \mathrm{[1]}]^{+}$ & 0.15 & $0.3 \mu \mathrm{g} / \mathrm{mL}$ \\
\hline
\end{tabular}

To confirm the cleavage activity of $[\mathbf{1}]^{+}$on the DNA, UV spectroscopic analysis was performed for the control pBR 322 DNA and DNA with different concentrations of the complex (Table 3). The concentration of the DNA showed a gradual decrease with increasing concentrations of the complex (Figure S6). The concentration of DNA sample can be checked by the use of UV spectrophotometry. DNA absorbs UV light very efficiently which makes it possible to detect and quantify at a concentration as low as $2.5 \mathrm{ng} / \mu \mathrm{L}$. The nitrogenous bases in nucleotides have an absorption maximum at about $260 \mathrm{~nm}$. The DNA concentration was calculated using the formula, DNA concentration $(\mu \mathrm{g} / \mathrm{mL})=(\mathrm{OD}$ $260) \times($ dilution factor $) \times(50 \mu \mathrm{g} \mathrm{DNA} / \mathrm{mL}) /(1 \mathrm{OD} 260$ unit). The control had $6 \mu \mathrm{g} / \mathrm{mL}$ of DNA. There was a gradual decrease in the concentration of the DNA when added with increasing concentrations of $[\mathbf{1}]^{+}$complex. This clearly shows that the complex played a major role in cleavage of pBR 322 DNA.

\subsection{Anti-cancer activity of the $[1]^{+}$complex}

It is now well accepted that metal coordination compounds with metal-ligand exchange rates comparable to cell-division processes, often appear to be highly active as anti-cancer agents. ${ }^{38 \mathrm{~b}} \mathrm{~A}$ all third generation drugs (vide supra) appear to bind to a guanine-N7 site and this binding seems to be essential for the effect induced in DNA. Different compounds, however, appear to have different binding kinetics, and also the structural details of the resulting DNA adducts appear to differ to some degree. ${ }^{38 c}$ The anti-cancer activity associated with $[\mathbf{1}]^{+}$is also associated with the presence of two fairly labile cis ligands and two phenanthroline ligands that are inert to substitution under biological conditions.

\section{7a 3-(4,5-dimethylthiazol-2-yl)-2,5-diphenyltetrazo-} lium bromide (MTT) Assay: The present [Co(phen $)_{2}$ $\left.\mathrm{Cl}_{2}\right]^{+},[1]^{+}$complex has the ability to strongly bind and cleave DNA in the absence of an external agent and DNA cleavage is considered as an important step for a drug to act as an anti-cancer agent. ${ }^{38-40}$ Thus, the cytotoxicity of the $[\mathbf{1}]^{+}$dissolved in DMSO was investigated against a human hepatocarcinoma cell line (HepG2) adopting MTT assay. The $\mathrm{IC}_{50}$ values of [1] ${ }^{+}$ were obtained by plotting the cell viability against the concentration of the complex (Figure S7). The results revealed that the $\mathrm{IC}_{50}$ at $48 \mathrm{~h}(170 \pm 0.2 \mu \mathrm{M})$ is lower than that at $24 \mathrm{~h}(175 \pm 0.3 \mu \mathrm{M})$ clearly indicating that the complex exhibits cytotoxicity against HepG2 in dose- and duration-dependent manner. Thus, the cytotoxicity exhibited by the complex is consistent with its strong binding with DNA, and its efficiency in cleaving DNA in the absence of an external agent is responsible for its potency to induce cell death through different modes of interaction between the cationic complex and DNA.

3.7b AO/EB staining: Apoptotic cell death is known as characterized by different cellular changes such as 
cell shrinkage, nuclear condensation, DNA fragmentation, membrane blebbing and formation of apoptotic bodies. These apoptotic characteristics as produced in human hepatocarcinoma cell (HepG2) by $[\mathbf{1}]^{+}$were analyzed adopting $\mathrm{AO} / \mathrm{EB}$ staining. In this staining method, the fluorescence pattern depends on the viability and membrane integrity of the cells. In general, dead cells are permeable to ethidium bromide and fluoresce in orange-red, whereas live cells are permeable to acridine orange only and thus fluoresce in green. The cytological changes which were observed in the treated cells are classified into four types based on the fluorescence emission and morphological features of chromatin condensation in the AO/EB stained nuclei: i) Viable cells, which are having highly organized nuclei, fluoresce in green. ii) Early apoptotic cells, which show nuclear condensation, emit orange-green fluorescence. iii) Late apoptotic cells, with highly condensed or fragmented chromatin, fluoresce orange to red. iv) Necrotic cells fluoresce orange to red, with no indication of chromatin fragmentation. All these morphological changes were observed after the treatment of cancer cells with the complex. Figure 6 indicates the apoptotic morphologies induced by $[1]^{+}$at $\mathrm{IC}_{50}$ concentration for $24 \mathrm{~h}$. The cobalt(III) complex, $[\mathbf{1}]^{+}$being a cationic molecule with two chlorine atoms at cis position $(<\mathrm{Cl}-\mathrm{Co}-\mathrm{Cl}=$ $92^{\circ}$ ) and labile groups at cisoid position around metal centres, is of considerable attraction in biology, specially as anticance agents. ${ }^{41}$ The cisoid labiles groups facilitate the path of substitution of the labile groups by the nitrogenous base (purine and pyrimidine) of the DNA and the $[1]^{+}$-DNA adduct enhances distortion in DNA molecules which causes apoptosis of the affected cells. On the other hand, $\left[\mathrm{Co}(\mathrm{phen})_{2} \mathrm{Cl}_{2}\right]^{+}$has two phenanthroline ligands which can intercalate into nitrogenous base pairs and elongate the DNA to some extent. Intercalative binding can also kill the affected DNA molecules. Figure 7 shows the efficacy of $[1]^{+}$to induce apoptosis in $53 \%$ of cells when treated for $24 \mathrm{hr}$ and there is no indication of necrotic cell death compared to untreated controls. The $\mathrm{IC}_{50}$ values and morphological changes consolidate the potential anticancer activity of the molecule. However, further studies are needed in this direction to decipher the molecular mechanisms underlying the mode of cell death induced by $[1]^{+}$.

3.7c Hoechst Staining: Morphological changes in the nucleus and chromatin were revealed by Hoechst 33528 staining method. The cells treated with $\mathrm{IC}_{50}$ concentration of the complex showed some changes in their morphology of nuclei compared to the control untreated nuclei. In the untreated control cells the nuclei

\section{AO/EB}
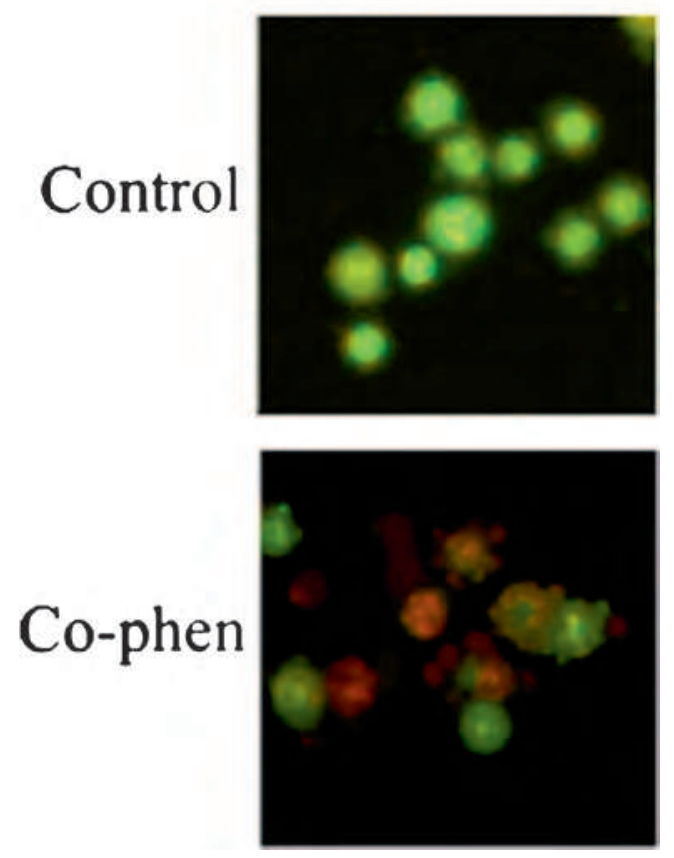

Figure 6. Representative morphological changes observed for $[1]^{+}$with AO/EB staining against HepG2 cells at $24 \mathrm{~h}$ incubation.

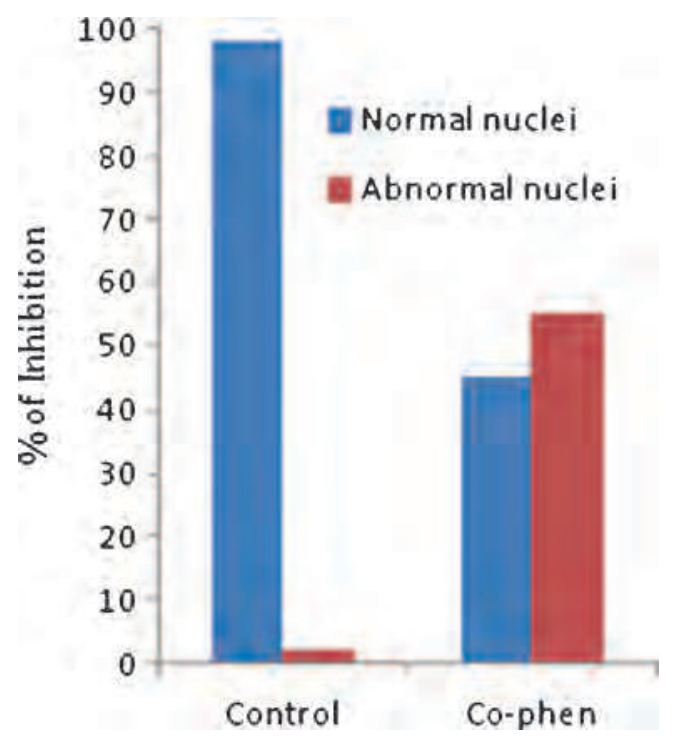

Figure 7. The effect of $[\mathbf{1}]^{+}$on HepG2 cell as revealed in acridine orange and ethidium bromide staining. Relative percentage of morphological changes was determined and classified into three categories: viable, apoptosis and necrosis as compared with the control cells after $24 \mathrm{~h}$ incubation.

were round with intact chromatin while after treatment with the complex for $24 \mathrm{~h}$ changes such as chromatin marginalization, condensation and fragmentation were 


\section{Hoechst}

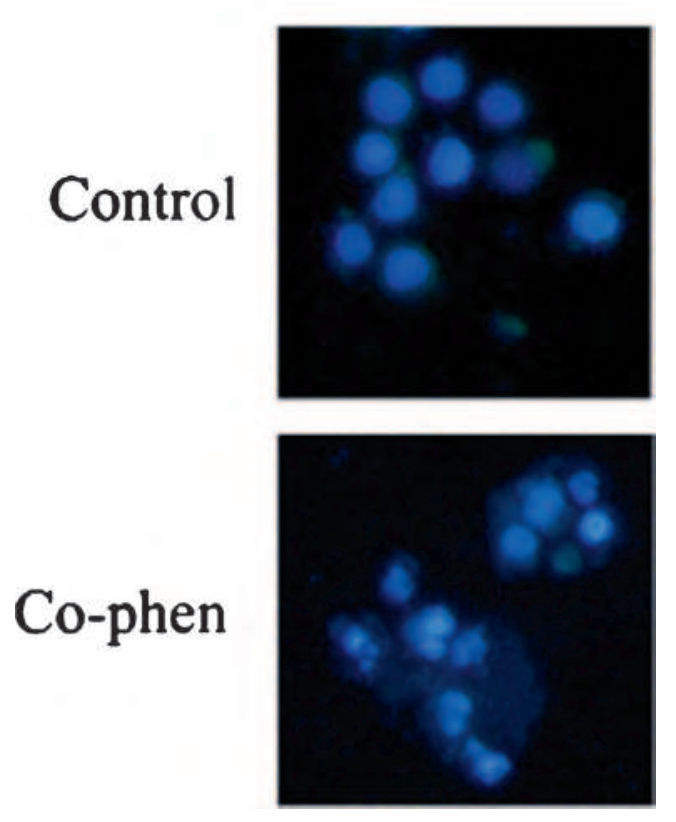

Figure 8. Representative morphological changes observed for $[\mathbf{1}]^{+}$with Hoechst 33258 staining against HepG2 at $24 \mathrm{~h}$ incubation.

observed. Figure 8 indicates the apoptotic nuclear morphology induced at $\mathrm{IC}_{50}$ concentration by the complex for $24 \mathrm{~h}$. It is interesting that $55 \%$ of treated cells exhibited abnormal nuclei (Figure 9).

\subsection{Thermogravimetric analysis}

The thermal behaviour of the complexes $[1] \mathrm{NO}_{3} \cdot 3 \mathrm{H}_{2} \mathrm{O}$ and $[1] \mathrm{NO}_{3} \cdot \mathrm{CH}_{3} \mathrm{CO}_{2} \mathrm{H} \cdot \mathrm{H}_{2} \mathrm{O}$ were followed up to $700^{\circ} \mathrm{C}$ in a static nitrogen atmosphere with a heating rate of $10^{\circ} \mathrm{C}$ per minute. Thermal analysis of $[1] \mathrm{NO}_{3} \cdot 3 \mathrm{H}_{2} \mathrm{O}$ shows that the loss in the temperature range 100 $197^{\circ} \mathrm{C}$ is $6.15 \%$ (figure $\mathrm{S} 8$ ), corresponding to two water molecules. The loss of total solvent molecules (16.1\%) at higher temperature $\left(100-275^{\circ} \mathrm{C}\right)$ is attributed to the strong interaction of the water-nitrate anions. The release of two coordinated chlorine atoms takes place in the second step $\left(275.48-316.80^{\circ} \mathrm{C}\right)$. The experimental mass loss $19.081 \%$ agrees well with the calculated mass loss $14.55 \%$. The residual part of the phenanthroline moieties takes place in the last step.

In the case of $[1] \mathrm{NO}_{3} \cdot \mathrm{CH}_{3} \mathrm{CO}_{2} \mathrm{H} \cdot \mathrm{H}_{2} \mathrm{O}$, there is continuous loss of solvent that starts at about $40^{\circ} \mathrm{C}$ and the release of acetic acid-water-nitrate occurs up to $289^{\circ} \mathrm{C}$ (Figure S9). The next step between $289.81^{\circ} \mathrm{C}$ and $425.08^{\circ} \mathrm{C}$ corresponds with the loss of two coordinated chlorine atoms and the residual part of the phenanthroline moieties take place in the last step $\left(425.08-626.51{ }^{\circ} \mathrm{C}\right)$.

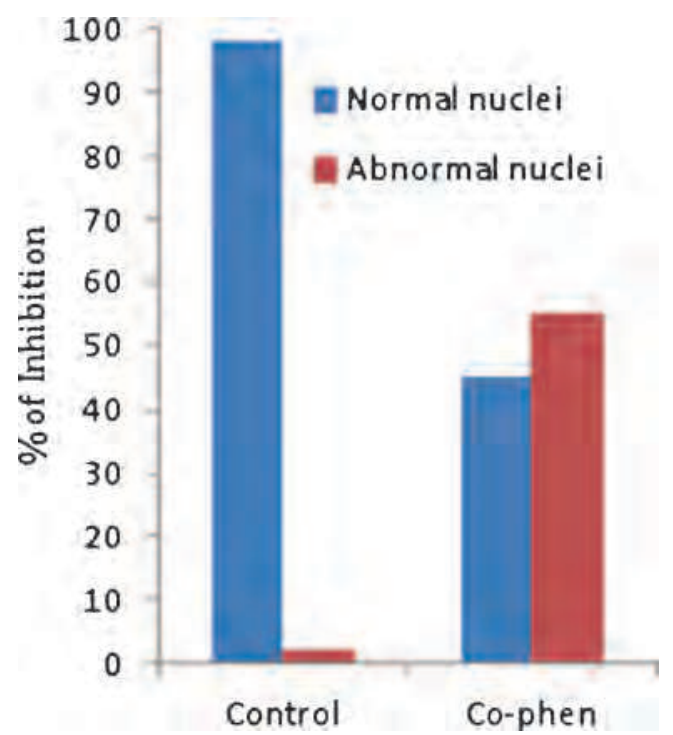

Figure 9. The effect of $[\mathbf{1}]^{+}$on HepG2 cell as revealed in Hoechst staining. Relative percentage of morphological changes was determined and classified into two categories: normal and abnormal nuclei as compared with the control cells after $24 \mathrm{~h}$ incubation.

\section{Conclusions}

We have synthesized and crystallographically characterized two mononuclear cis-Co(III)-phenanthroline compounds. The cationic cobalt(III) complexex, [1] ${ }^{+}$ exhibits very efficient catalytic activity in saturated oxygen environment towards 3,5-ditertbutylcatechol with $\mathrm{k}_{\text {cat }}$ value $9.65 \times 10^{2} \mathrm{~h}^{-1}$. [1] $]^{+}$is one of the few examples of mononuclear cobalt(III) complexes containing catalyst of catecholase activity for which both the single crystal $\mathrm{X}$-ray structure and $\mathrm{K}_{\mathrm{cat}}$ value have been determined. Besides, $[\mathbf{1}]^{+}$being a mononuclear cobalt(III) complex with non-copper centre is mimicking an enzyme with a dicopper active site. $[1]^{+}$induces very efficient cleavage of double-stranded DNA without the requirement of activating agents and exhibits important cytotoxicity against human hepatocarcinoma cell line (HepG2) in terms of damaging the DNA in cancer cells. Moreover, detailed experimentation related to DNA interaction, cleavage and cytotoxicity on this complex will help to develop clinically relevant information for possible new anticancer agents.

\section{Supplementary Information}

Crystallographic data are available free of charge from The Director, CCDC, 12 Union Road, Cambridge, CB2 1EZ, UK (fax: +44-1223-336033; 
E-mail: deposit@ccdc.cam.ac.uk or www: http://www. ccdc.cam.ac.uk) upon request, quoting deposition number CCDC 829003 for [1] $\mathrm{NO}_{3} \cdot 3 \mathrm{H}_{2} \mathrm{O}$ and and CCDC 975400 for $[1] \mathrm{NO}_{3} \cdot \mathrm{CH}_{3} \mathrm{CO}_{2} \mathrm{H} \cdot \mathrm{H}_{2} \mathrm{O}$. Figures $\mathrm{S} 1-\mathrm{S} 9$ and tables S1-S3 are available in the online version at www. ias.ac.in/chemsci.

\section{Acknowledgements}

The work was supported financially by the Department of Science and Technology (DST), New Delhi, India under FAST TRACK SCHEME for YOUNG SCIENTIST (NO. SB/FT/CS-088/2013 dtd. 21/05/2014). B. Biswas also gratefully acknowledges the financial support from the University Grant Commission, New Delhi, India (F. No. PSW-84/12-13(ERO) dated $05 / 02 / 2013)$. B. Biswas is highly thankful to IACS, Kolkata for facilitating proton NMR and mass spectrometric studies.

\section{References}

1. (a) Long E C and Barton J K 1990 Acc. Chem. Res. 23 271; (b) Selvi P T, Evans H S, Palaniandavar M 2005 J. Inorg. Biochem. 992110

2. (a) Sammes P G and Yahioglu G 1994 Chem. Soc. Rev. 23 327; (b) Shields T P, Barton J K, 1995 Biochemistry 34 15037; (c) Vaidyanathan V G, Nair B U 2003 J. Inorg. Biochem. 94121

3. (a) Barton J K and Raphael A L 1984 J. Am. Chem. Soc. 106 2466; (b) Wang X L, Chao H, Li H, Hong X L, Liu Y J, Tan L F and Ji L N 2004 J. Inorg. Biochem. 981143

4. (a) Sitlani A S, Long E C, Pyle A M, Barton J K 1992 J. Am. Chem. Soc. 114 2303; (b) Dey D, Pal S, Chandraleka S, Dhanasekaran D, Kole N and Biswas B 2014 J. Indian Chem. Soc. 911267

5. (a) Chan S and Wong W T 1995 Coord. Chem. Rev. 138 219; (b) Zhen Q-X, Ye B-H, Zhang Q-L, Liu J-G, Li H, Ji L-N and Wang L 1999 J. Inorg. Biochem. 76 47; (c) Dey D, Kaur G, Ranjani A, Gyathri L, Chakraborty P, Adhikary J, Pasan J, Dhanasekaran D, Choudhury A R, Akbarsha M A, Kole N and Biswas B 2014 Eur. J. Inorg. Chem. 3350

6. (a) Pratviel G, Bernadou J and Meunier B 1998 Adv. Inorg. Chem. 45 251; (b) Shimakoshi H, Kaieda T, Matsuo T, Sato H and Hisaeda Y 2003 Tetrahedron Lett. 44 5197; (c) Biswas B, Mitra P and Ghosh R 2013 J. Indian Chem. Soc. 901311

7. (a) Liang F, Wang P, Zhou X, Li T, Li Z Y, Lin H K, Gao D Z, Zheng C Y and Wu CT 2004 Bioorg. Med. Chem. Lett. 14 1901; (b) Biswas B, Mitra M, Pal A, Basu A, Rajalakshmi S, Mitra P, Aliaga-Alcalde N, Kumar G S, Nair B U and Ghosh R 2013 Ind. J. Chem. Sect. A 52A 1576
8. (a) Biswas B, Patra M, Dutta S, Ganguly M and Kole N 2013 J. Chem. Sci. 125 1445; (b) Pal A, Biswas B, Mondal S K, Lin C-H and Ghosh R 2012 Polyhedron 31 671

9. (a) Parshall G and Ittel S (Eds.)1992 Homogeneous Catalysis $2^{\text {nd }}$ edition (New York: John Wiley); (b) Biswas B, Al-Hunaiti A, Räisänen M T, Ansalone S, Leskelä M, Repo T, Chen Y-T, Tsai H-L, Naik A D, Railliet A P, Garcia Y, Ghosh R and Kole N 2012 Eur. J. Inorg. Chem. 4479

10. Cornils B and Herrmann W (Eds.) 1996 Applied Homogeneous Catalysis with Organometallic Compounds Vol. 1 (Weinheim: VCH)

11. Anastas P and Warner J 1997 In Green Chemistry: Theory and Practice (Oxford: Oxford University Press)

12. (a) Puzari A and Jubaraj B 2002 J. Mol. Cat. A Chem. 187 149; (b) Biswas B, Mitra M, Adhikary J, Krishna G R, Bag P P, Reddy C M, Aliaga-Alcalde N, Chattopadhyay T, Das D and Ghosh R 2013 Polyhedron 53264

13. (a) Gates B 1992 In Catalytic Chemistry (Hoboken: John Wiley); (b) Dey D, Kaur G, Patra M, Choudhury A R, Kole N and Biswas B 2014 Inorg. Chim. Acta 421 335

14. Foote C, Valentine J, Greenberg A and Liebman J 1995 In Active Oxygen in Chemistry, SEARCH Series, Vol. 2 (Kluver)

15. (a) Mayer A M and Harel E 1979 Phytochem 18 193; (b) Simándi T L and Simándi L I 1998 React Kinet. Catal. Lett. 65 301; (c) Simándi L I and Simándi T L 1998 J. Chem. Soc. Dalton Trans. 3275; (d) Biswas A, Das L K and Ghosh A 2013 Polyhedron 61253

16. (a) Selmeczi K, Reglier M, Giorgi M and Speier G 2003 Coord. Chem. Rev. 245 191; (b) Gerdemann C, Eicken C, Krebs B 2002 Acc. Chem. Res. 35 183; (c) Guha A, Chattopadhyay T, Paul N D, Mukherjee M, Goswami S, Mondal TK, Zangrando E and Das D 2012 Inorg. Chem. 518750

17. (a) Than R, Feldmann A A and Krebs B 1999 Coord. Chem. Rev. 182 211; (d) Solomon E I, Sundaram U M, Machonkin T E 1996 Chem. Rev. 96 2563; (f) Klabunde T, Eicken C, Sacchettini J C and Krebs B 1998 Nat. Struct. Biol. 5 1084; (g) C Eicken, Krebs B and Sacchettini J C 1999 Curr. Opin. Struct. Biol. 9677

18. (a) Dervall B J 1961 Nature 189 311; (b) Koval I A, Gamez P, Belle C, Selmeczi K, Reedijk J 2006 Chem. Soc. Rev. 35 814; (c) Kitajima N and Moro-oka Y 1994 Chem. Rev. 94737

19. Youssef NS El-Zahany E, El-Seidy A M A, Caselli A and Cenini S 2009 J. Mol. Cat. A 308159

20. (a) Chan T L, To C T, Liao B-S, Liu S-T and Chan K S 2012 Eur. J. Inorg. Chem. 485; (b) Arzberger S, Soper J, Anderson O P, la Cour A and Wicholas M 1999 Inorg. Chem. 38757

21. (a) Simandi L I, Barna T, Argay G and Simandi T L 1995 Inorg. Chem. 34 6337; (b) Chakrabarty R, Sarmah P, Saha B, Chakravorty S and Das B K 2009 Inorg. Chem. 486371

22. Ghosh S, Barve A C, Kumbhar A A, Kumbhar A S, Puranik V G, Datar P A, Sonawane U B and Joshi R R 2006 J. Inorg. Biochem. 100331

23. SHELXTL 5.10 Bruker Analytical X-ray Instruments Inc.,Karlsruche, Germany (1997) 
24. Farrugia L J, ORTEP-32 for Windows, University of Glasgow, Scotland (1998)

25. Mosmann T 1983 J. Immun. Met. 6555

26. Spector D L, Goldman R D and Leinwand L A 1998 In Cell: A Laboratory Manual. Culture and Biochemical Analysis of Cells Vol. 1 (New York: Cold Spring Harbor Laboratory Press)

27. Nakamoto K 1997 In Infrared and Raman Spectra of Inorganic and Coordination Compounds part B: Applications in Coordination, Organometallic and Bioinorganic Chemistry (New York: John Wiley) p. 116

28. Sole J G, Bausa L E and Jaque D 2005 In An Introduction to Optical Spectroscopy of Inorganic Solids (John Wiley)

29. Tsuruya S, Yanai S-I and Masai M 1986 Inorg. Chem. 25141

30. Zippel F, Ahlers F, Werner R, Haase W, Nolting H-F and Krebs B 1996 Inorg. Chem. 353409

31. Banu K S, Chattopadhyay T, Banerjee A, Mukherjee M, Bhattacharya S, Patra G K, Zangrando E and Das D 2009 Dalton Trans. 8755

32. Majumder S, Mondal S, Lemoineb P and Mohanta S 2013 Dalton Trans. 424561

33. Ghosh R, Mitra M and Raghavaiah P 2015 New J. Chem. 39200
34. Dey S K and Mukherjee A 2014 New J. Chem. 384985

35. Banerjee A, Guha A, Adhikary J, Khan A, Manna K, Dey S, Zangrando E and Das D 2013 Polyhedron 60102

36. Vaidyanathan V G and Nair B U 2003 J. Inorg. Biochem. 94121

37. (a) Liu X W, Li J, Li H, Zheng K C, Chao H and Ji L N 2006 J Inorg Biochem 100 385; (b) Chao H, Mei W J, Huang Q W and Ji L N 2002 J Inorg Biochem 92165

38. (a) Basile L A, Raphael A L and Barton J K 1987 J. Am. Chem. Soc. 109 7550; (b) Hartwig J F and Lippard S J 1992 J. Am. Chem. Soc. 114 5646; (c) Reedijk J 2009 Eur. J. Inorg. Chem. 1303

39. (a) Ramakrishnan S, Suresh E, Riyasdeen A, Periasamy V S, Akbarsha M A, Palaniandavar M 2011 Dalton Trans. 40 3245; (b) Satyanaryana S, Dabrowiak J C and Chaires J B 1993 Biochemistry 32 2573; (c) Wang X 2010 Anticancer Agents Med. Chem. 10396

40. (a) Wang X and Guo Z 2013 Chem. Soc. Rev. 42 202; (b) Tabassum S, Parveen S and Arjmand F 2005 Acta Biomater. 1 677; (c) Pasternack R F, Gibbs E J and Villafranca J J 1983 Biochemistry 222406

41. (a) Hannon M J 2007 Pure Appl. Chem. 79 2243; (b) Oberoi H S, Nukolova N V, Kabanov A V and Bronich T K 2013 Adv. Drug Delivery Rev. 651667 